J. Dairy Sci. 95:3569-3578

http://dx.doi.org/10.3168/jds.2011-5163

(C) American Dairy Science Association ${ }^{\circledR}, 2012$.

\title{
Milk fatty acid composition and production performance of Danish Holstein and Danish Jersey cows fed different amounts of linseed and rapeseed
}

\author{
M. K. Larsen, ${ }^{\star 1}$ L. Hymøller, $†$ D. B. Brask-Pedersen, $†$ and M. R. Weisbjerg† \\ *Department of Food Science, and \\ †Department of Animal Science, AU Foulum, Aarhus University, Blichers Allé 20, PO Box 50, DK-8830 Tjele, Denmark
}

\begin{abstract}
Fat supplements are used in diets for dairy cows to increase energy intake and milk production and the fatty acid composition of the feed affects milk fatty acid composition. A total of 74 Danish Holstein and 41 Danish Jersey cows were divided into 4 groups and the cows within each group were fed a mixed ration supplemented with $0,3.5,6.8$, or $10.2 \%$ of dry matter of a linseed:rapeseed (1:3) mixture during lactation wk 6 to 30. Milk yield, fat, and lactose contents were not affected by treatments for Danish Holsteins, whereas these parameters increased when increased amounts of oilseeds were fed to Danish Jerseys. For both breeds, milk protein content decreased when increased amounts of oilseeds were fed. The milk fatty acid composition showed higher concentrations of saturated fatty acids and lower concentrations of unsaturated fatty acids in milk fat from Danish Jerseys compared with Danish Holsteins. Increased amounts of oilseeds in feed increased milk fat concentration of all C18 fatty acids except C18:2 n-6, whereas the content of $\mathrm{C} 6$ to $\mathrm{C} 14$, $\mathrm{C} 11$ to $\mathrm{C} 17$, and in particular, C16, decreased. This effect was more pronounced for Danish Holsteins than for Danish Jerseys. The apparent recovery of C18:2 n-6 and C18:3 n-3 decreased when increased amounts of oilseeds were fed; however, this was most likely due to increased amounts of fatty acid from feed used for other energy demands than milk production. It was concluded that up to $6.8 \%$ of oilseed supplementation can be fed without production problems and, in many cases, with positive production responses, including an improved milk fatty acid profile.
\end{abstract}

Key words: oilseed, milk production, milk fatty acid composition

Received November 21, 2011.

Accepted March 9, 2012.

${ }^{1}$ Corresponding author: mette.larsen@agrsci.dk

\section{INTRODUCTION}

Fats are used in diets for high-producing dairy cows to increase energy intake and milk production. Furthermore, the FA composition of the produced milk can be manipulated by altering the FA composition of fats in the feed. The presence of particular FA in foods has attracted public interest, because a high intake of SFA has been associated with elevated concentrations of blood cholesterol in humans and increased risk of coronary heart diseases (Lunn and Theobald, 2006). A specific preventive effect of $\alpha$-linolenic acid (C18:3 n-3) on coronary heart diseases has been shown (Ascherio et al., 1996), and milk enriched with n-3 PUFA and oleic acid (C18:1 cis-9) has been shown to decrease the risk of cardiovascular diseases (Carrero et al., 2004). A specific decrease in the content of palmitic acid (C16:0) in milk is desired in combination with an increase in the content of cis MUFA and cis PUFA (Givens, 2010).

The FA composition of milk consists of a range of FA. Short- and medium-chain SFA (C4 to C14) originate from mammary de novo synthesis; C16:0 may originate from this de novo synthesis or from feed. Longer-chain FA in milk (mainly C18 FA) originate from feed or from mobilized body fat. Mammary desaturation of SFA is the main source of cis-9 MUFA (Grummer, 1991). Polyunsaturated FA derive from feed; however, biohydrogenation of dietary unsaturated FA by rumen bacteria before intestinal absorption causes the degree of saturation of the FA absorbed in ruminants to be higher than the degree of saturation of FA consumed (Weisbjerg et al., 1992; Jenkins, 1993; Doreau and Ferlay, 1994). The main PUFA in feed and linoleic and linolenic acid are usually biohydrogenated to a very high degree. Doreau and Ferlay (1994) compared several studies and found that the percentage of biohydrogenation of linoleic acid ranged from 70 to $95 \%$ and the percentage of biohydrogenation of linolenic acid from 85 to 100\%. A marked increase in the supply of absorbable PUFA in the small intestine would, therefore, require a relatively large intake of unsaturated FA, unless the degree of hydrogenation in the rumen is effectively reduced. 
Feeding dairy cattle large amounts of unsaturated FA has a negative effect on rumen function; for example, by decreasing the fiber digestibility and the acetate-topropionate ratio (Chilliard, 1993; Harvatine and Allen, 2006), but at the same time decreasing methane losses (Beauchemin et al., 2007). The severity of these negative effects is determined by different factors such as the quantity of fat per se and the composition of the fat source with respect to FA chain length and degree of saturation (Weisbjerg et al., 1992; Harvatine and Allen, 2006); for example, unsaturated FA are toxic to protozoa and cellulolytic bacteria (Jenkins, 1993), and oils have a more negative effect on the rumen environment than do oilseeds and cakes (Jenkins, 1993).

Protecting fats and FA against microbial activity reduces the degree of biohydrogenation of unsaturated FA and the negative effect of fat supplementation on cell wall degradation of ingested plant material. However, the effects of the existing protection technologies are limited or very costly (Jenkins and Bridges, 2007). Offering oilseeds to ruminants instead of oils provides natural protection against biohydrogenation of lipids in the rumen (Ekeren et al., 1992).

The aim of the present study was to investigate the response in FA composition of the produced milk, feed intake, milk yield, and BW changes when feeding dairy cows of 2 different breeds [Danish Holstein (DH) and Danish Jersey (DJ)] increasing levels of unsaturated fat from a mixture of linseed and rapeseed during wk 6 to 30 of lactation. Linseed and rapeseed were chosen because they can be grown under Northern European conditions and because the major FA of linseeds, C18:3 n-3, was expected to increase milk fat content of this FA.

Table 1. Mixed ration composition (\% of DM) calculated from the feed intake in the different treatment groups

\begin{tabular}{|c|c|c|c|c|}
\hline \multirow[b]{2}{*}{ Mixed ration composition } & \multicolumn{4}{|c|}{ Treatment } \\
\hline & F0 & F1 & $\mathrm{F} 2$ & F3 \\
\hline Grass clover silage & 31.0 & 31.2 & 30.5 & 30.7 \\
\hline Corn silage & 31.9 & 32.6 & 32.0 & 32.2 \\
\hline Soybean meal, extracted & 7.8 & 7.9 & 7.8 & 7.9 \\
\hline Rapeseed meal, extracted & 5.0 & 5.1 & 5.0 & 5.1 \\
\hline Barley, rolled & 10.0 & 6.7 & 3.3 & - \\
\hline Linseed & - & 0.9 & 1.7 & 2.6 \\
\hline Rapeseed & - & 2.6 & 5.1 & 7.6 \\
\hline Concentrate (in AMS unit) ${ }^{1}$ & 12.9 & 11.5 & 13.1 & 12.5 \\
\hline Vitamin and mineral mixture $^{2}$ & 1.0 & 1.0 & 1.0 & 1.0 \\
\hline Salt $(\mathrm{NaCl})$ & 0.5 & 0.5 & 0.5 & 0.5 \\
\hline
\end{tabular}

${ }^{1} \mathrm{AMS}=$ automatic milking system.

${ }^{2}$ Composition of vitamin and mineral mixture (per kilogram): vitamin A 566,000 IU; vitamin D3 101,600 IU; $\alpha$-tocopherol 1,029.2 mg; D- $\alpha$ tocopherol $757.7 \mathrm{mg}$; calcium $290 \mathrm{~g}$; magnesium $62 \mathrm{~g}$; sulfur $39 \mathrm{~g}$; manganese 3,843 mg; copper 1,385 mg; zinc 6,667 mg; iodine $198.3 \mathrm{mg}$; cobalt $31.2 \mathrm{mg}$; selenium $27.9 \mathrm{mg}$.

\section{MATERIALS AND METHODS}

\section{Animals and Experimental Design}

Animal experiments complied with the Danish Ministry of Justice Law No. 726 (September 9, 1993) concerning experiments with animals and care of experimental animals. A total of 115 cows of the DJ or DH breed were allocated to different treatments according to lactation number (first and later) and expected calving date. Cows were allocated to 4 different concentrations of fat $(\mathbf{F} 0, \mathbf{F 1}, \mathbf{F 2}$, and F3) in a mixed ration (MR) during wk 6 to 30 of lactation. During wk 0 to 5 of lactation, all cows were fed the F0 ration, which was a standard low-fat dairy ration.

\section{Housing and Management}

Experiments were carried out at the Danish Cattle Research Centre (Tjele, Denmark) during 2009. Cows were kept in a loose-housing system with slatted floors and cubicles with mattresses. A free cow-traffic system was applied for access to an automatic milking system (AMS) from DeLaval AB (Tumba, Sweden). Within the dairy unit, cows were organized in 3 groups (AMS groups), 1 with DJ cows and 2 with DH cows, and each group had access to 1 automatic milking unit (AMU) equipped with a device for automatic measurement of milk yield and milk sampling. Additionally the AMU were equipped with a device for concentrate feeding and weighing of concentrate refusals at the end of each cow visit. Below each AMU, a platform scale from Danvægt A/S (Hinnerup, Denmark) for automatic recording of cow BW was installed. For automatic recording of MR intake, the Insentec RIC system (Insentec BV, Marknesse, the Netherlands) was used. The facilities and management procedures at the Danish Cattle Research Centre are described in detail by Bossen et al. (2009) and Bossen and Weisbjerg (2009).

\section{Feeds and Mixed Rations}

Four different corn and grass clover silage-based MR were used to obtain 4 fat levels (treatments F0, F1, F2, and F3) where barley was partly or totally substituted with ground rapeseed (double-low variety) and linseed (3:1) on a DM basis, as shown in Table 1. The chemical composition of individual ingredients is shown in Table 2 .

\section{Data Collection}

Information on MR intake, concentrate intake, milk yield, milk composition, BW, and BCS was obtained as 
described by Bossen et al. (2009) and Bossen and Weisbjerg (2009). Energy-corrected milk was calculated as described by Sjaunja et al. (1991).

\section{Laboratory Feed Analyses}

Chemical analyses of individual feedstuffs and adjustment of feed rations during the study were carried out as described by Bossen et al. (2009). Feed FA composition was analyzed as described by Palmquist and Jenkins (2003).

\section{Milk FA Composition and FA Recovery}

For each treatment (F0, F1, F2, and F3), cows that calved within the same 20 -wk period were selected for analysis of milk FA composition. Milk was sampled in lactation wk 8 ( $\pm 1 \mathrm{wk}), 20( \pm 2 \mathrm{wk})$, and $30( \pm 2$ wk). Milk samples were frozen at $-20^{\circ} \mathrm{C}$ on the day of sampling and stored until analysis. Milk FA composition was analyzed as described by Larsen et al. (2011).

The apparent recoveries of FA from feed to milk were calculated on an individual-cow basis based on the average daily milk yield, milk fat concentration, and FA composition analyzed and the average daily FA intake from feed in the particular week. The relative amount of C18:2 n-6 and C18:3 n-3, respectively, of total C18 FA was calculated for milk as well as feed. The ratio between these unsaturated proportions of C18 FA of milk and feed were used to assess the effect of feed treatment on degree of biohydrogenation.

\section{Statistical Analysis}

Analysis of variance on production data was performed using the MIXED models procedure of SAS (SAS Institute Inc., Cary, NC). Initial analyses showed a significant interaction between breeds and treatments, so subsequent data analyses were performed on DH and DJ cows separately. Covariates of the different response variables in individual cows were formed from the results obtained during wk 1 to 4 after calving. Week 5 was omitted because the feed change took place that week. When analyzing milk and ECM yield; fat, protein, and lactose concentration in milk; protein-tofat ratio in milk; DMI; intake of various nutrients and individual FA; and the production efficiency, the following model was used in wk 6 to 30 of lactation in $\mathrm{DH}$ cows: $Y_{i j k l}=\mu+C O V+\alpha_{i}+\beta_{j}+(\alpha \beta)_{i j}+\gamma_{k}+E_{i j k l}$ $+\varepsilon_{i j k l}$, where $Y_{i j k l}$ is the dependent variable, $\mu$ is the overall mean, $C O V$ is the individual covariate, $\alpha_{i}$ is the fixed effect of treatment $i\left(\mathrm{~F} 0, \mathrm{~F} 1, \mathrm{~F} 2\right.$, or F3), $\beta_{j}$ is the fixed effect of lactation number $j$ (first or later), $(\alpha \beta)_{i j}$ is the effect of the interaction between lactation period treatment $i$ and lactation number $j, \gamma_{k}$ is the fixed effect of week number $k(6,7, \ldots, 30), E_{i j k l}$ is the random effect of the DH AMS group $l$ (1 or 2$)$, and $\varepsilon_{i j k l}$ is the random residual error. Random effects were assumed normally distributed with mean value 0 and constant variance $E_{i j k l} \sim \mathrm{N}\left(0, \sigma_{\mathrm{E}}^{2}\right)$ and $\varepsilon_{i j k l} \sim \mathrm{N}\left(0, \sigma^{2}\right)$. To account for the covariance structure of the repeated measures during consecutive weeks within individual cows the repeated statement for the MIXED procedure in SAS was used (Littell et al., 2006). The best model fit was obtained using the autoregressive first-order covariance structure $[\mathrm{AR}(1)]$. When analyzing the weekly changes in BW and BCS between wk 6 and 30 of lactation, slopes of BW and BCS curves from individual cows were estimated in the regression (REG) procedure in SAS and subjected to ANOVA in the MIXED procedure in SAS; a $C O V$ and week numbers were not part of the model and analysis was performed without repeated measures. Data from DJ cows were analyzed similar to DH cows except for omitting the effect of AMS group from the models. The $P$-values for linear and quadratic effects of total FA content in total ration DM were calculated using the contrast statement.

Due to the more limited data on milk FA composition the following statistical model was chosen: $Y_{i j k l}=$ $\mu+\alpha_{i}+\beta_{j}+(\alpha \beta)_{i j}+\gamma_{k}+\varepsilon_{i j k l}$, where $Y_{i j k l}$ is the de-

Table 2. Chemical composition (g/kg of DM) of feedstuffs

\begin{tabular}{|c|c|c|c|c|c|c|c|c|}
\hline $\begin{array}{l}\text { Chemical } \\
\text { composition }\end{array}$ & $\begin{array}{c}\text { Soybean } \\
\text { meal }\end{array}$ & $\begin{array}{c}\text { Rapeseed } \\
\text { meal }\end{array}$ & Barley & Linseed & Rapeseed & $\begin{array}{l}\text { Grass } \\
\text { clover } \\
\text { silage }\end{array}$ & $\begin{array}{l}\text { Corn } \\
\text { silage }\end{array}$ & $\begin{array}{l}\text { Concentrate } \\
\text { mixture }\end{array}$ \\
\hline Ash & 73 & 80 & 20 & 37 & 42 & 104 & 29 & 72 \\
\hline Fat & 26 & 42 & 30 & 436 & 485 & 35 & 31 & 36 \\
\hline Total $\mathrm{FA}^{1}$ & 27 & 32 & 26 & 375 & 409 & 23 & 29 & 26 \\
\hline Sugar & 370 & 115 & 27 & 27 & 67 & 83 & 19 & 75 \\
\hline
\end{tabular}

${ }^{1}$ Sum of FA C16, C18:0, C18:1 n-9 cis, C18:2, and C18:3. 
Table 3. Daily intake (kg of DM/d) of nutrients and energy of Danish Holstein (DH) cows in response to 4 different levels of fat content (F0 to F3) in the mixed ration during wk 6 to 30 of lactation

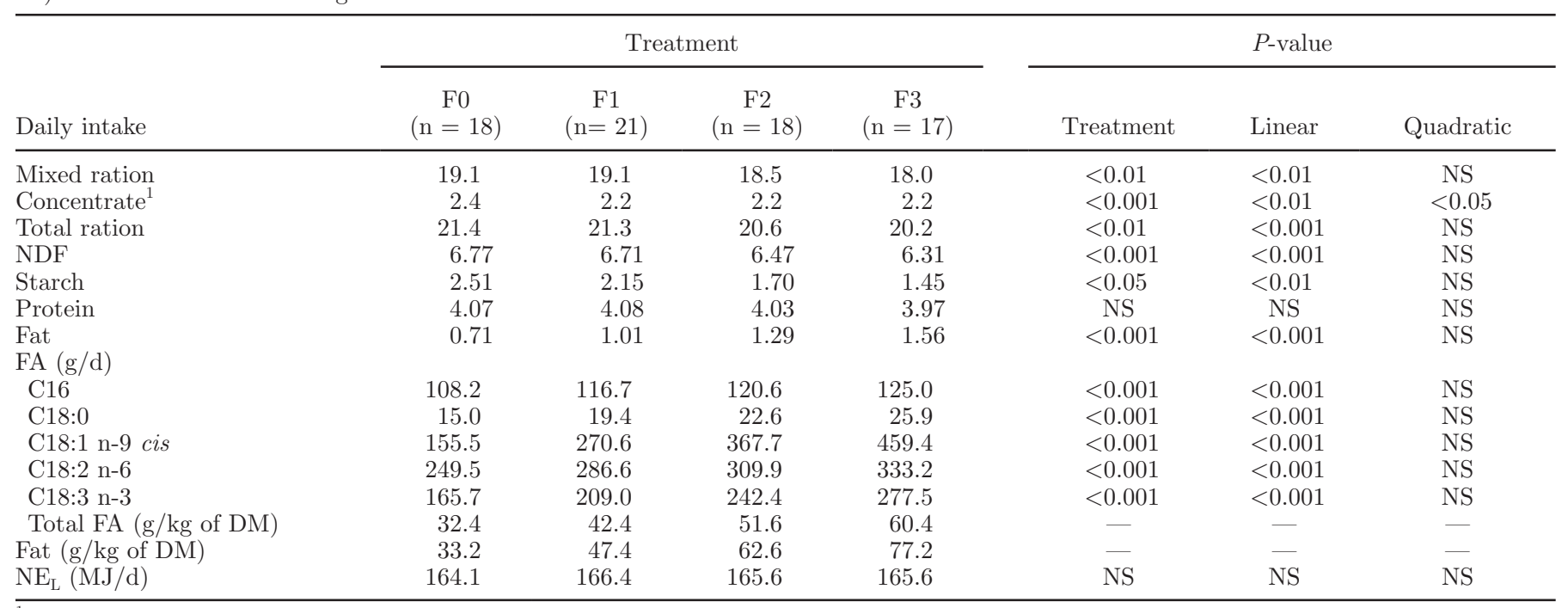

${ }^{1}$ Concentrate fed in the automatic milking unit.

pendent variable, $\mu$ is the overall mean, $\alpha_{i}$ is the fixed effect of treatment $i$ (F0, F1, F2, or F3), $\beta_{j}$ is the fixed effect of breed $j(\mathrm{DH}$ or $\mathrm{DJ}),(\alpha \beta)_{i j}$ is the effect of the interaction between treatment $i$ and breed $j, \gamma_{k}$ is the fixed effect of week number $k(8,20$, or 30$)$, and $\varepsilon_{i j k l}$ is the random residual error. Differences were considered statistically significant when $P \leq 0.05$ and results are presented as least squares means.

\section{RESULTS}

\section{DM, Nutrient, and Energy Intake}

Results of chemical analyses of individual feed ingredients are presented in Table 2 . The DM contents of the 4 different MR were approximately $40 \%$. Intake of DM and nutrients in DH cows are shown in Table 3 and in DJ cows in Table 4. Calculation of nutrient intake was based on results of chemical analyses (Table 2). The DMI was affected by treatment in both DH $(P \leq 0.01)$ and DJ cows $(P \leq 0.01)$ but particularly pronounced in first-lactation DH cows where the DMI decreased significantly after changing from the $\mathrm{F} 0$ treatment to one of the treatments F1 to F3 at wk 5 of lactation (data not shown). The energy intake in megajoules per day was, however, unaffected by the treatments. The fat intake and intake of unsaturated FA increased significantly, as expected, when the content of oilseeds in the MR increased through the treatments F1 to F3 in both breeds $(P \leq 0.001)$. Treatment effects on the protein intake were not significant but showed a decreasing trend, with increasing oilseed levels in the MR corresponding to the decreasing DMI.

\section{BW Gain and BCS}

The largest daily BW gains were found in the F2 treatment where DH cows increased their BW by 0.40 $\mathrm{kg} / \mathrm{d}$ and DJ cows by $0.32 \mathrm{~kg} / \mathrm{d}$, respectively (Table $5)$. The BCS of DH cows on all treatments increased throughout the study, with the largest increase in the F2 treatment group. In DJ cows, the F0 treatment resulted in a decrease in BCS, whereas treatments F1 to F3 resulted in increasing BCS, with the lowest increase in the F3 treatment group (data not shown).

\section{Milk Yield and Milk Composition}

In DH cows, no significant effects of treatment were observed on milk yield, ECM yield, and fat and lactose contents, whereas the protein concentration decreased linearly through the treatments F0 to F3 from 33.3 to $32.1 \mathrm{~g} / \mathrm{kg}(P \leq 0.05)$. In DJ cows, a significant effect of treatments was observed on milk yield and ECM $(P$ $\leq 0.05$ ), where the daily milk yield increased from 24.6 in F0 to $26.1 \mathrm{~kg} / \mathrm{d}$ in F3 and ECM yield followed the same trend (Table 6). The fat content in milk from DJ cows tended to be affected by treatments $(P=0.09)$ and the highest fat content was found in the F1 treatment group. The protein content in milk from DJ cows decreased linearly through the treatments F0 to F3 from 42.2 to $38.7 \mathrm{~g} / \mathrm{kg}(P \leq 0.001)$, whereas the lactose content increased linearly in all treatment groups $(P \leq$ 0.001 ; Table 6 ). The protein-to-fat ratio generally decreased linearly with increasing levels of oilseeds in the MR $(P \leq 0.001$; Table 6$)$. First-lactation DJ cows on the F3 treatment increased their milk and ECM yield 
Table 4. Daily intake (kg of DM/d) of nutrients and energy of Danish Jersey (DJ) cows in response to 4 different levels of fat content (F0 to F3) in the mixed ration during wk 6 to 30 of lactation

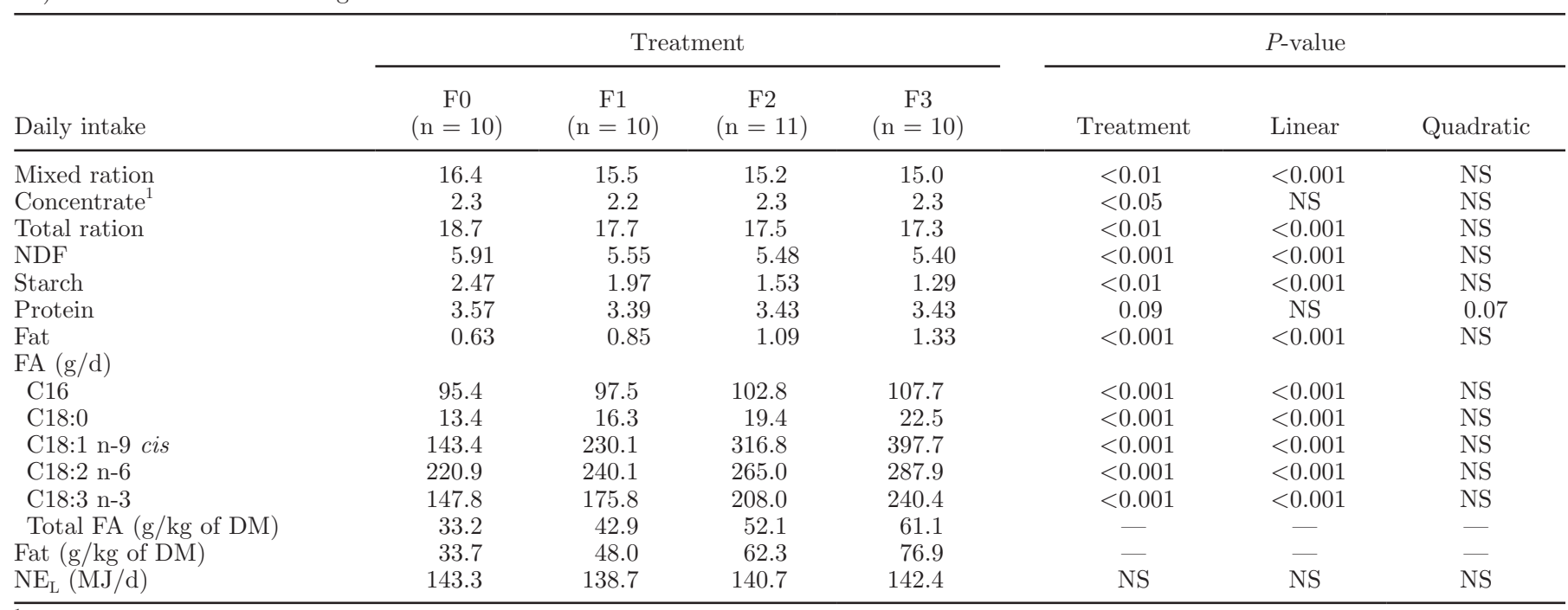

${ }^{1}$ Concentrate fed in the automatic milking unit (AMU).

throughout the study and had the highest yield of all first-lactation DJ treatment groups (data not shown), but at the same time, they had the lowest protein content in the produced milk (data not shown).

\section{Production Efficiency}

The production efficiency, measured as kilograms of ECM per megajoules of $\mathrm{NE}_{\mathrm{L}}$, decreased linearly through the treatments F0 to F3 in DH cows from 0.219 to $0.208 \mathrm{~kg}$ of $\mathrm{ECM} / \mathrm{MJ}$ of $\mathrm{NE}_{\mathrm{L}}(P \leq 0.001)$, whereas the production efficiency in DJ cows increased linearly from 0.217 to $0.232 \mathrm{~kg}$ of ECM/MJ of $\mathrm{NE}_{\mathrm{L}}(P \leq 0.01$; Table 6).

\section{FA in Milk}

The results of milk FA analysis are shown in Table 7. Major breed differences included higher content of unsaturated FA in milk from DH and higher content of saturated FA in milk from DJ. This difference was also expressed by the higher desaturation indices of $\mathrm{DH}$. Increased amounts of oilseeds increased the content of all C18 FA in milk except C18:2 n-6, whereas the con- tent of $\mathrm{C} 6$ to $\mathrm{C} 14, \mathrm{C} 11$ to $\mathrm{C} 17$, and in particular, C16, decreased. Also C18 and CLA desaturation indices decreased with increased amounts of oilseeds in the feed.

Apparent recoveries of all FA decreased with increasing amounts of oilseeds in the feed. Recoveries of the unsaturated FA C18:2 n-6 and C18:3 n-3 were not affected by breed, whereas the overall recovery of C16 as well as C18 FA was higher for DJ than for DH. The degree of biohydrogenation of C18:2 n- 6 as well as C18:3 n-3 was higher for DJ than for DH, and differences between treatments showed the highest biohydrogenation of C18:2 n- 6 for the F0 treatment, whereas the biohydrogenation of C18:3 n-3 was highest for the F3 treatment. Recovery of the total amount of $\mathrm{C} 18 \mathrm{FA}$ as affected by breed, stage of lactation, and treatment is shown in Figure 1. For both breeds, the recovery decreased during lactation and decreased when increased amounts of oilseeds were fed.

\section{DISCUSSION}

All cows showed decreasing DMI with increasing levels of oilseeds in the MR but were able to maintain the same energy intake due to the higher energy density of

Table 5. Change in BW ( $\Delta \mathrm{kg} / \mathrm{d})$ of Danish Holstein (DH) and Danish Jersey (DJ) cows in response to 4 different levels of fat (F0 to F3) content in the mixed ration during wk 6 to 30 of lactation

\begin{tabular}{lcccccccc}
\hline & \multicolumn{4}{c}{ Treatment } & & \multicolumn{3}{c}{$P$-value } \\
\cline { 2 - 3 } \cline { 8 - 10 } Breed & F0 & F1 & F2 & F3 & & Treatment & Linear & Quadratic \\
\hline DH & 0.26 & 0.28 & 0.40 & 0.28 & & $<0.001$ & $<0.05$ & $<0.001$ \\
DJ & 0.31 & 0.24 & 0.32 & 0.28 & & $<0.01$ & NS & NS \\
\hline
\end{tabular}


Table 6. Daily milking frequency, milk yield, composition of milk, and efficiency of milk production in relation to $\mathrm{NE}_{\mathrm{L}}$ of Danish Holsteins (DH) and Danish Jerseys (DJ) in response to 4 different levels of fat content (F0 to F3) in the mixed ration during wk 6 to 30 of lactation

\begin{tabular}{|c|c|c|c|c|c|c|c|}
\hline \multirow[b]{2}{*}{ Item } & \multicolumn{4}{|c|}{ Treatment } & \multicolumn{3}{|c|}{$P$-value } \\
\hline & F0 & F1 & $\mathrm{F} 2$ & F3 & Treatment & Linear & Quadratic \\
\hline $\mathrm{DH}$ & 2.7 & 2.4 & 2.4 & 2.5 & $<0.01$ & $<0.01$ & $<0.01$ \\
\hline DJ & 3.1 & 2.9 & 3.1 & 3.0 & NS & NS & NS \\
\hline \multicolumn{8}{|c|}{ Milk yield $(\mathrm{kg} / \mathrm{d})$} \\
\hline $\mathrm{DH}^{\circ}$ & 37.4 & 36.4 & 35.4 & 36.7 & NS & NS & 0.09 \\
\hline $\mathrm{DH}$ & 36.0 & 35.5 & 34.3 & 35.0 & NS & 0.08 & NS \\
\hline DJ & 31.1 & 31.8 & 32.7 & 32.2 & $<0.05$ & $<0.05$ & NS \\
\hline \multicolumn{8}{|c|}{ Fat $(\mathrm{g} / \mathrm{kg})$} \\
\hline $\mathrm{DH}$ & 37.4 & 38.7 & 38.4 & 38.4 & NS & NS & NS \\
\hline DJ & 57.2 & 58.6 & 56.8 & 55.9 & 0.09 & NS & 0.09 \\
\hline \multicolumn{8}{|c|}{ Protein $(\mathrm{g} / \mathrm{kg})$} \\
\hline $\mathrm{DH}$ & 33.3 & 32.9 & 32.8 & 32.1 & 0.08 & $<0.05$ & NS \\
\hline $\mathrm{DH}$ & 49.8 & 49.8 & 49.6 & 49.6 & NS & NS & NS \\
\hline DJ & 48.6 & 49.4 & 49.8 & 49.9 & $<0.001$ & $<0.001$ & 0.08 \\
\hline \multicolumn{8}{|c|}{$\mathrm{kg}$ of $\mathrm{ECM} / \mathrm{MJ}$ of $\mathrm{NE}_{\mathrm{L}}$} \\
\hline $\mathrm{DH}$ & 0.219 & 0.215 & 0.207 & 0.208 & $<0.001$ & $<0.001$ & NS \\
\hline DJ & 0.217 & 0.226 & 0.231 & 0.232 & $<0.01$ & $<0.01$ & NS \\
\hline
\end{tabular}

${ }^{1}$ Energy-corrected milk calculated as described by Sjaunja et al. (1991).

the oilseed-containing rations. Decreased DMI is common when feeding unsaturated fats and oils, either due to metabolic feed intake regulation or because unsaturated FA decrease the digestibility of the NDF fraction of the feed (Weisbjerg and Børsting, 1989; Pantoja et al., 1994), which probably results in low passage rates through the rumen and increased rumen filling. Only in first-lactation DH cows did the decreased DMI of the F3 treatment result in a significantly decreased milk yield compared with the F0 to $\mathrm{F} 2$ treatments in first-lactation DH cows (data not shown). However, the limited number of cows in this treatment group may have affected the outcome.

The fat content of the produced milk was unaffected by the level of oilseeds in the MR in DH cows, whereas the fat content of the milk in DJ cows was lower at the F3 level of oilseeds in the MR than at the remaining levels. However, total fat production increased from $1.40 \mathrm{~kg} / \mathrm{d}(\mathrm{F} 0)$ to $1.46 \mathrm{~kg} / \mathrm{d}$ (F3) with a linear effect of increased oilseed level in the MR $(P<0.01)$. Decreased fat contents in milk after feeding diets high in fat is probably caused by altered rumen fermentation and a resulting change in the relation between propionic and acetic acid in the rumen, as shown by Harvatine and Allen (2006). Both breeds tended to show the expected quadric effect of treatment on the milk fat content but the effect was not significant in DJ $(P=0.09)$ or in
DH $(P=0.29)$. Protein content in the milk was generally decreased at the F3 oilseed level in the MR, as expected when the fat content of the feed is increased (Chilliard, 1993). In the current study, the decreased protein content of the milk at the high level of oilseeds in the MR resulted in a decreased protein-to-fat ratio in the produced milk.

The effect of breed on milk FA composition was similar to that previously reported (White et al., 2001; Arnould and Soyeurt, 2009). These differences included higher content of monounsaturated cis-9 FA and CLA in milk from DH, which was mainly due to a higher desaturase activity (Soyeurt et al., 2008). The concentrations of C18:2 n-6 and C18:3 n-3 were higher in milk from DH compared with DJ, and the degree of biohydrogenation was higher in DJ than $\mathrm{DH}$; however, the apparent recovery of these PUFA was not different between breeds. Thus, concentration differences were, to some extent, caused by differences in ruminal biohydrogenation of PUFA. However, also the higher content of de novo FA in milk from DJ was diluting FA from feed and resulting in lower PUFA concentrations.

The concentration of C18:3 n-3 in milk was increased at increased levels of oilseed, although for $\mathrm{DH}$, this increase moderated as the oilseed level increased from F2 to F3. The purpose of selecting linseed as a feed ingredient was its high content of $\mathrm{C} 18: 3 \mathrm{n}-3$ and the 
Table 7. Milk FA composition and recovery of FA from feed to milk of Danish Holsteins (DH) and Danish Jerseys (DJ) in response to 4 different levels of fat content (F0 to F3) in the mixed ration

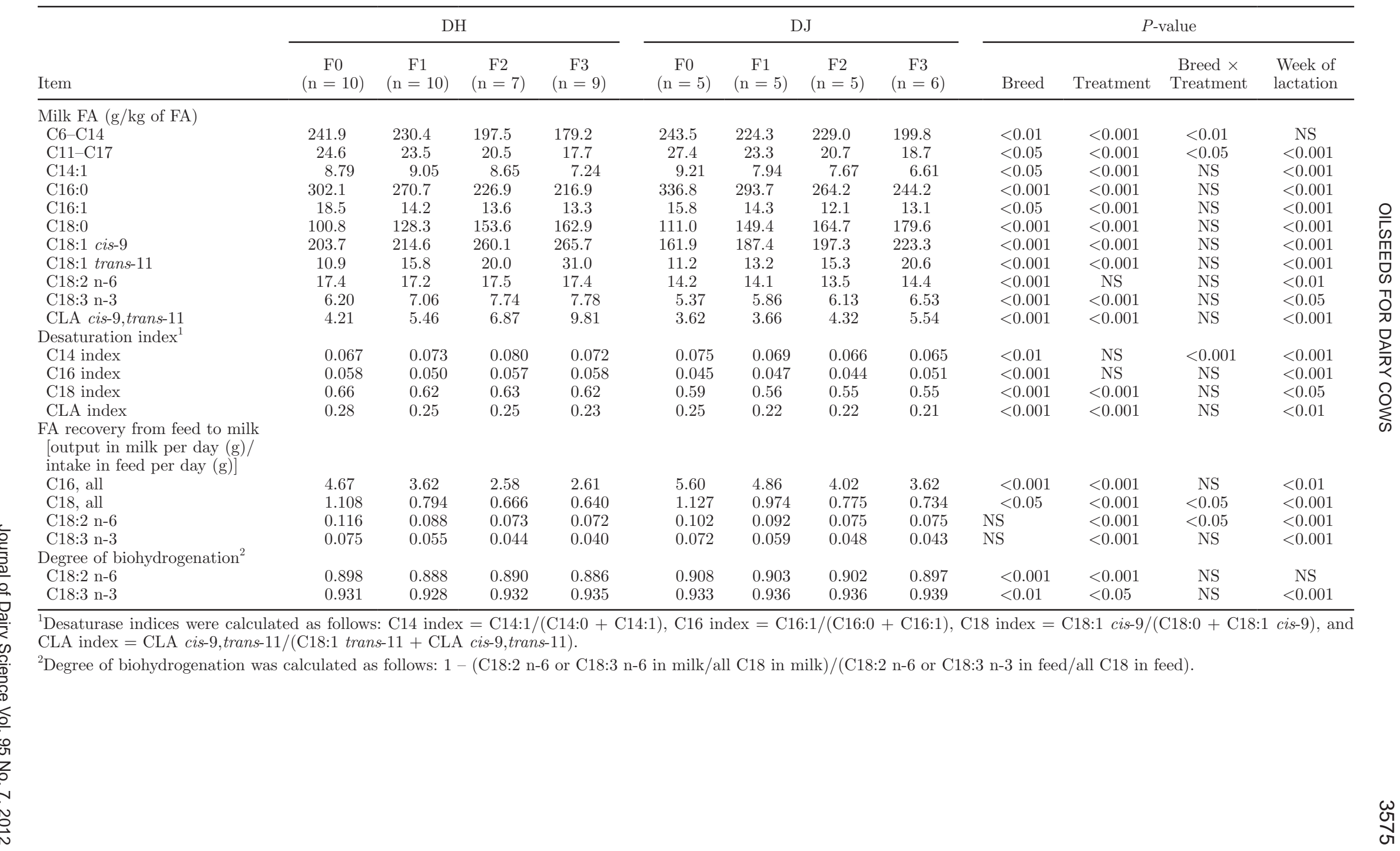




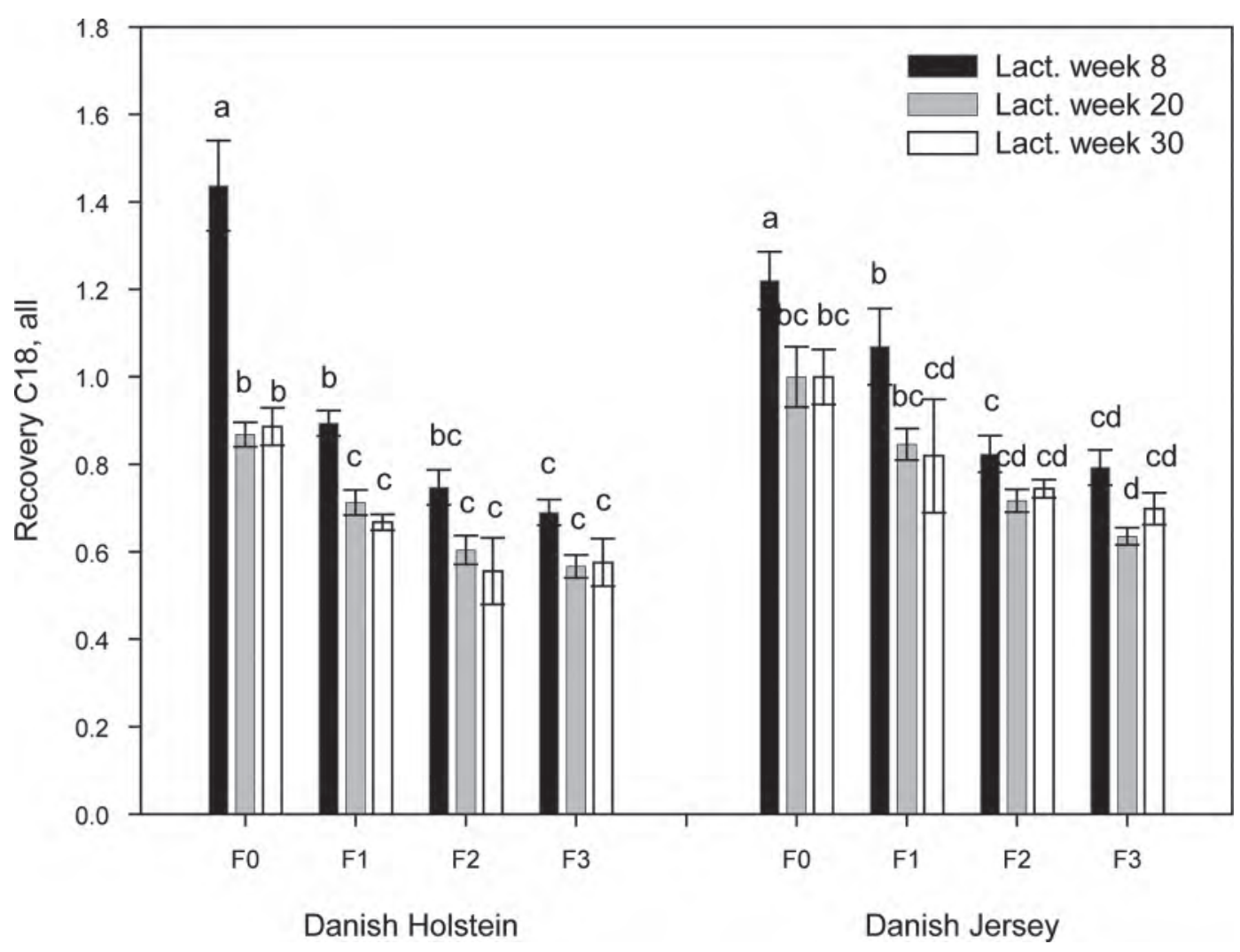

Figure 1. Recovery of all C18 [output in milk per day $(\mathrm{g}) /$ intake in feed per day $(\mathrm{g})$ ], reported as means and standard errors, of Danish Holstein and Danish Jersey in response to 4 different levels of fat content in the mixed ration (F0 to F3) and 3 stages of lactation (Lact.). Different indexes (a, b, c, and d) within breeds indicate significant differences $(P \leq 0.05)$.

increased levels of oilseeds in the feed did increase the milk fat content of $\mathrm{C} 18: 3 \mathrm{n}-3$. However, others have reported larger linear increases in the milk content of C18:3 n-3 after feeding increased amounts of linseed at levels similar to those in the present study (Hurtaud et al., 2010) or higher (Collomb et al., 2004; Deaville et al., 2004). The effects obtained by Hurtaud et al. (2010; extruded linseed) and Deaville et al. (2004; feed product containing heat-treated linseed) could be related to protection of oilseeds, as extruded oilseeds have been reported to be more effective than whole linseed in increasing milk C18:3 n-3 content (Chilliard et al., 2009). However, others have shown no differences between raw and heat-treated linseed (Gonthier et al., 2005). When other types of oilseeds are used, milk fat composition is affected according to the FA composition of the given oilseeds and Chilliard et al. (2009) showed how feeding sunflower seed and linseed increased the milk fat content of C18:2 n-6 and C18:3 n-3, respectively. The C18:1 trans-11 as well as CLA increased markedly more between F2 and F3 compared with the other 2 increments, especially for DH. This observation indicates that the final biohydrogenation of $\mathrm{C} 18: 1$ trans-11 in the rumen was decreased with the high oilseed level. The C18:1 trans-11 peak was a mixture of C18:1 trans-10 and C18:1 trans-11 and at high oilseed levels a higher proportion of C18:1 trans-10 may be formed (Roy et al., 2006; Hurtaud et al., 2010). In the present study, the smaller increase in CLA cis-9,trans-11 and lower CLA indices at higher amounts of oilseeds in the ration indicated that a higher proportion of C18:1 trans-10 was generated.

The apparent recoveries of C18:2 n- 6 and C18:3 n-3 decreased when increased amounts of these FA were fed. This caused marginal responses to decrease with increasing amounts of oilseeds. Similar effects on calculated recoveries of C18:2 n-6 and C18:3 n-3 have been reported previously (Khiaosa-Ard et al., 2010). Feeding increasing amounts of linseed has been shown to decrease the transfer of $\mathrm{C} 18: 3 \mathrm{n}-3$ from feed to milk at levels close to those obtained in the present study (Akraim et al., 2007; Hurtaud et al., 2010). However, in contrast to our findings, Hurtaud et al. (2010) reported a transfer of $19.2 \%$ of C18:3 n-3 from control feed without oilseeds to milk. This might be due to a very low supply of C18:3 n-3 from feed because the control feed 
is maize silage and concentrate, as opposed to our present study in which grass silage was a significant source of $\mathrm{C} 18: 3 \mathrm{n}-3$.

The decreased apparent recoveries of C18:3 n-3 and C18:2 n-6 could be due to more effective biohydrogenation or due to a greater part of the fat being used for other purposes than secretion as milk fat when high levels of oilseeds were fed. The calculated values for biohydrogenation showed only minor differences between treatments, so the differences in apparent recoveries of unsaturated FA were probably due to FA being utilized for alternative purposes or lower efficiency of absorption or inclusion in milk fat.

The average recovery of all $\mathrm{C} 18$ was $>1$ for treatment F0 where no oilseeds were included and Figure 1 shows how these values decreased during lactation, indicating that some of the C18 FA in milk originated from mobilized fat, especially in lactation wk 8. Also for treatment $\mathrm{F} 1$, the recovery decreased during lactation, whereas the F2 and F3 treatments did not show differences in recovery of all $\mathrm{C} 18$. This was due to the higher total intake of C18 FA where a higher proportion of the feed FA was used for other energy demands or for deposition, and it was not possible to distinguish between $\mathrm{C} 18 \mathrm{FA}$ in milk from body fat mobilization and feed.

The recovery of $\mathrm{C} 16$ could be interpreted as the contribution of $\mathrm{C} 16$ from feed corresponding to a value of 1 plus the contribution of C16 from de novo synthesis. Thus, the present recovery values correspond to a de novo synthesis between 62 and $82 \%$ of the C16 in milk. The present results show that the de novo synthesis decreased when increased amounts of oilseeds were fed, mainly due to the lower concentration of $\mathrm{C} 16$ in milk but also due to the increased supply from feed. The lower de novo synthesis when oilseeds were fed was also reflected in the decreased concentrations of C6 to C14 in milk. The analytical conditions in the present study did not allow for proper quantification of $\mathrm{C} 4$; hence, differences in de novo synthesis of this FA, as affected by oilseed feeding, was not studied. However, others have reported smaller or no effects of oilseed feeding on milk fat $\mathrm{C} 4$ concentrations and larger effects, especially on $\mathrm{C} 10$ to $\mathrm{C} 14$ concentrations (Collomb et al., 2004; Gonthier et al., 2005; Chilliard et al., 2009; Hurtaud et al., 2010).

The C14 index is regarded as the best desaturase index for expression of the apparent desaturase activity, as C14:0 and C14:1 are of mammary origin (Lock and Garnsworthy, 2002). In the present study, the C14 index and the C16 index were not affected by treatment, which indicates that the different levels of oilseeds did not affect the enzymatic activity. However, the C18 index as well as the CLA index decreased when oilseeds were included in feed, but others have reported opposite effects (Lock and Garnsworthy, 2002) due to higher amounts of C18:1cis-9 and CLA being transferred from rumen to milk. The decrease in CLA index in the present results could be due to a higher proportion of $\mathrm{C} 18: 1$ trans-10 in the combined peak of C18:1 trans-10 and C18:1 trans-11. The decrease in C18 index could be caused by a less-effective desaturation when the concentration of C18:0 increased as higher amounts of oilseeds were fed.

\section{CONCLUSIONS}

Adding up to $6.8 \%$ oilseeds in the $\mathrm{MR}$ for $\mathrm{DH}$ and DJ cows did not decrease milk production and, in many cases, even positive effects on production of the increased oilseed intake were found. Hence, cows coped well with high levels of dietary unsaturated fat from oilseeds, except for a few exceptions on the $10.2 \%$ oilseeds treatment level, particularly in first-lactation DH and later-lactation DJ cows. Inclusion of oilseeds in feed decreased the content of C16 and increased the content of C18 MUFA and PUFA in milk fat, which is considered beneficial for human health. These effects were most pronounced in $\mathrm{DH}$ cows, but the additional effect of increasing the oilseed content of the MR from 6.8 to $10.2 \%$ was limited.

\section{ACKNOWLEDGMENTS}

Arla Foods Amba (Viby J, Denmark), the Danish Cattle Association (Skejby, Denmark), and the Danish Ministry of Food, Agriculture and Fisheries (Copenhagen, Denmark) are acknowledged for financial support.

\section{REFERENCES}

Akraim, F., M. C. Nicot, R. Juaneda, and F. Enjalbert. 2007. Conjugated linolenic acid (CLnA), conjugated linoleic acid (CLA) and other biohydrogenation intermediates in plasma and milk fat of cows fed raw or extruded linseed. Animal 1:835-843.

Arnould, V. M.-R., and H. Soyeurt. 2009. Genetic variability of milk fatty acids. J. Appl. Genet. 50:29-39.

Ascherio, A., E. B. Rimm, E. L. Giovannucci, D. Spiegelman, M. Stampfer, and W. C. Willett. 1996. Dietary fat and risk of coronary heart disease in men: Cohort follow up study in the United States. BMJ 313:84-90.

Beauchemin, K. A., S. M. McGinn, and H. V. Petit. 2007. Methane abatement strategies for cattle: Lipid supplementation of diets. Can. J. Anim. Sci. 87:431-440.

Bossen, D., and M. R. Weisbjerg. 2009. Allocation of feed based on individual cow live weight changes: II: Effect on milk production. Livest. Sci. 126:273-285.

Bossen, D., M. R. Weisbjerg, L. Munksgaard, and S. Højsgaard. 2009. Allocation of feed based on individual dairy cow live weight changes: I: Feed intake and live weight changes during lactation. Livest. Sci. 126:252-272.

Carrero, J. J., L. Baró, J. Fonollá, M. González-Santiago, A. MartínezFérez, R. Castillo, J. Jiménez, J. J. Boza, and E. López-Huertas. 
2004. Cardiovascular effects of milk enriched with $\omega-3$ polyunsaturated fatty acids, oleic acid, folic acid, and vitamins $\mathrm{E}$ and $\mathrm{B}_{6}$ in volunteers with mild hyperlipidemia. Nutrition 20:521-527.

Chilliard, Y. 1993. Dietary fat and adipose tissue metabolism in ruminants, pigs, and rodents: A review. J. Dairy Sci. 76:3897-3931.

Chilliard, Y., C. Martin, J. Rouel, and M. Doreau. 2009. Milk fatty acids in dairy cows fed whole crude linseed, extruded linseed, or linseed oil, and their relationship with methane output. J. Dairy Sci. 92:5199-5211.

Collomb, M., H. Sollberger, U. Bütikofer, R. Sieber, W. Stoll, and W. Schaeren. 2004. Impact of a basal diet of hay and fodder beet supplemented with rapeseed, linseed and sunflowerseed on the fatty acid composition of milk fat. Int. Dairy J. 14:549-559.

Deaville, E. R., D. I. Givens, and J. S. Blake. 2004. Dietary supplements of whole linseed and vitamin $\mathrm{E}$ to increase levels of alphalinolenic acid and vitamin $\mathrm{E}$ in bovine milk. Anim. Res. 53:3-12.

Doreau, M., and A. Ferlay. 1994. Digestion and utilisation of fatty acids by ruminants. Anim. Feed Sci. Technol. 45:379-396.

Ekeren, P. A., D. R. Smith, D. K. Lunt, and S. B. Smith. 1992. Ruminal biohydrogenation of fatty acids from high-oleate sunflower seeds. J. Anim. Sci. 70:2574-2580.

Givens, D. I. 2010. Milk and meat in our diet: Good or bad for health? Animal 4:1941-1952.

Gonthier, C., A. F. Mustafa, D. R. Ouellet, P. Y. Chouinard, R. Berthiaume, and H. V. Petit. 2005. Feeding micronized and extruded flaxseed to dairy cows: Effects on blood parameters and milk fatty acid composition. J. Dairy Sci. 88:748-756.

Grummer, R. R. 1991. Effect of feed on the composition of milk fat. J. Dairy Sci. 74:3244-3257.

Harvatine, K. J., and M. S. Allen. 2006. Effects of fatty acid supplements on ruminal and total tract nutrient digestion in lactating dairy cows. J. Dairy Sci. 89:1092-1103.

Hurtaud, C., F. Faucon, S. Couvreur, and J.-L. Peyraud. 2010. Linear relationship between increasing amounts of extruded linseed in dairy cow diet and milk fatty acid composition and butter properties. J. Dairy Sci. 93:1429-1443.

Jenkins, T. C. 1993. Lipid metabolism in the rumen. J. Dairy Sci. 76:3851-3863.

Jenkins, T. C., and W. C. Bridges Jr. 2007. Protection of fatty acids against ruminal biohydrogenation in cattle. Eur. J. Lipid Sci. Technol. 109:778-789.

Khiaosa-Ard, R., F. Klevenhusen, C. R. Soliva, M. Kreuzer, and F. Leiber. 2010. Transfer of linoleic and linolenic acid from feed to milk in cows fed isoenergetic diets differing in proportion and origin of concentrates and roughages. J. Dairy Res. 77:331-336.
Larsen, T., M. K. Larsen, and N. C. Friggens. 2011. Enzymatic and fluorometric determination of triacylglycerols in cow milk and other opaque matrices. Food Chem. 125:1110-1115.

Littell, R. C., G. A. Milliken, W. W. Stroup, R. D. Wolfinger, and O. Schabenberger. 2006. SAS for MIXED models. 2nd ed. SAS Institute Inc., Cary, NC.

Lock, A. L., and P. C. Garnsworthy. 2002. Independent effects of dietary linoleic and linolenic fatty acids on the conjugated linoleic acid content of cows' milk. Anim. Sci. 74:163-176.

Lunn, J., and H. E. Theobald. 2006. The health effects of dietary unsaturated fatty acids. Nutr. Bull. 31:178-224.

Palmquist, D. L., and T. C. Jenkins. 2003. Challenges with fats and fatty acid methods. J. Anim. Sci. 81:3250-3254.

Pantoja, J., J. L. Firkins, M. L. Eastridge, and B. L. Hull. 1994. Effects of fat saturation and source of fiber on site of nutrient digestion and milk production by lactating dairy cows. J. Dairy Sci. $77: 2341-2356$.

Roy, A., A. Ferlay, K. J. Shingfield, and Y. Chilliard. 2006. Examination of the persistency of milk fatty acid composition responses to plant oils in cows given different basal diets, with particular emphasis on trans-C-18: 1 fatty acids and isomers of conjugated linoleic acid. Anim. Sci. 82:479-492.

Sjaunja, L. O., L. Baevre, L. Junkkarinen, J. Pedersen, and J. Setälä. 1991. A Nordic proposal for an energy corrected milk (ECM) formula. Pages 156-157 in EAAP publication 50: Performance recording of animals: State of the art 1990. Centre for Agricultural Publishing and Documentation (PUDOC), Wageningen, the Netherlands.

Soyeurt, H., F. Dehareng, P. Mayeres, C. Bertozzi, and N. Gengler. 2008. Variation of $\Delta^{9}$-desaturase activity in dairy cattle. J. Dairy Sci. 91:3211-3224.

Weisbjerg, M. R., and C. F. Børsting. 1989. Influence of fat and feed level on fiber digestibility in vitro and in sacco and on volatile fatty acid proportions in the rumen. Acta Vet. Scand. Suppl. 86:137-139.

Weisbjerg, M. R., T. Hvelplund, and C. F. Børsting. 1992. Digestibility of fatty acids in the gastrointestinal tract of dairy cows fed with tallow or saturated fats rich in stearic acid or palmitic acid. Acta Agric. Scand. A. Animal Sci. 42:115-120.

White, S. L., J. A. Bertrand, M. R. Wade, S. P. Washburn, J. T Green, and T. C. Jenkins. 2001. Comparison of fatty acid content of milk from jersey and Holstein cows consuming pasture or a total mixed ration. J. Dairy Sci. 84:2295-2301. 